\title{
Molecular Typing of Brucella melitensis and B. abortus From Human Blood Samples Using PCR-RFLP Method
}

\author{
Reza Mirnejad ${ }^{1}$, Mozafar Mohammadi ${ }^{1}$, Ali Majdi ${ }^{2}$, Niloufar Taghizoghi ${ }^{3}$, Vahhab Piranfar ${ }^{4,}$ \\ ${ }_{1}^{1}$ Molecular Biology Research Center, Baqiyatallah University of Medical Sciences, Tehran, IR Iran \\ 2 Young Researchers Club, Tonekabon Branch, Islamic Azad University, Tonekabon, IR Iran \\ 3 Bounty house, Stowage, Bellerbys College, London, United Kingdom \\ 4 Bounty house, Stowage, Bellerbys College, London, United Kingdom \\ ${ }^{*}$ Corresponding author: Vahhab Piranfar, Department of Biology, Tonekabon branch, Islamic Azad university of Tonekabon, Tonekabon, IR Iran. Tel: +98-937 130 7300, Fax: +98- \\ 2188039883, E-mail:vahhab.p@gmail.com.
}

Received: July 11, 2012; Revised: December 31, 2012; Accepted: January 27, 2013

\begin{abstract}
Background: Brucella is an intracellular parasite of the disease brucellosis throughout the world. Although several molecular typing methods are introduced to find DNA polymorphism that is able to identify Brucella species and biovars, but among these methods, detection of polymorphisms by PCR-RFLP has several advantages including the easy implementation, interpretation and the ease of use for large quantities of samples.

Objectives: In the current study, the technique was used for molecular typing of Brucella abortus and B. melitensis that was isolated from human blood samples.

Materials and Methods: Blood samples of 160 patients were transferred to Kerman clinical centers with chief complain of acute brucellosis and showed high blood serum level (about 1.80). Their DNAs were extracted by Phenol chloroform method, and the PCR was optimized by using the fragments of designed primers for omp2a and omp2b. Therefore PCR products were restricted by restriction endonuclease as PstI and Hinfi. Finally they were electrophoresed for analyzing the digestion results on agarose gels (2\%).

Results: In 160 blood samples that were studied with PCR technique, 52 cases obtained bands of 1100 bp for omp2a locus and 1200 bp for omp2b locus from within 52 positive samples by PCR-RFLP method 25 cases (48\%) were positive out of which $56 \%$ were B. melitensis biovar1 and $44 \%$ were $B$. abortus biovars of $3,5,6$ or 9 .

Conclusions: The results of this study showed that PCR-RFLP technique was a fast and applicable method especially for separation, detection and differentiation between species of B. melitensis and B.abortus biovars in blood sample. Also the presented data showed that B. melitensis biovar 1 was the prevalence biovar.
\end{abstract}

Keywords: Brucella abortus; B. melitensis ; RFLP; Molecular Typing

\section{Background}

Brucellosis is a bacterial disease caused by Brucella members and it is one of the important common diseases in human and animals and an important reason of abortion in animals (1-4). This disease is endemically found all around the world especially in Asian, African, North American and Mediterranean countries (5, 6). Annually so many people in the World are afflicted by this disease, hence, that is an important health problem in developing countries and its control in these areas is very important $(5,6)$. Several studies have shown that to control and prevent the disease, it is very important to have the epidemiological information. The microbiologists all over the world use various molecular and non-molecular methods to obtain this information (7).

The genus of Brucella includes several species and biovars. The difference between their species and biovars is mainly based on phenotypic characteristics of LPS antigens, sensitivity to colors, need to $\mathrm{CO} 2, \mathrm{H} 2 \mathrm{~S}$ production, metabolic features and phage typing $(8,9)$. But these methods are very difficult and their sensitivity is too low. On the other hand, since DNA homology for all species in the genus of Brucella is more than $90 \%$, so the attempt is providing accurate identification of Brucella species and biovars, by molecular methods $(8,10)$.

Several molecular typing methods are introduced to find DNA polymorphism that is able to identify the Brucella species and biovars, among which detection of

Implication for health policy/ practice/ research/medical education

Brucellosis is a disease endemically found all around the world especially in Mediterranean countries. Asian, African and North American countries are associated with this disease. DNA homology for all species in the genus of Brucella is more than $90 \%$, so now the attempt is to provide accurate identification of Brucella species and biovars by molecular methods. In this method by omp25, omp2 and omp31 loci, all Brucella species can be differentiated from each other and their biovars can be identified. In Iran, no study is done especially in clinical samples by this method, and the current study was the first time where molecular typing of $B$. melitensis and B. abortus isolated from blood clinical samples were used.

Copyright ( ) 2013, Ahvaz Jundishapur University of Medical Sciences; Licensee Kowsar Ltd. This is an Open Access article distributed under the terms of the Creative Commons Attribution License (http://creativecommons.org/licenses/by/3.0), which permits unrestricted use, distribution, and reproduction in any medium, provided the original work is properly cited. 
polymorphisms by PCR - RFLP has several advantages including the easy implementation, interpretation and use for large quantities of samples (11-13). In this method, by omp25, omp2 and omp31 loci and all Brucella species can be differentiated and their biovars identified (14). Several studies use these genes to differentiate Brucella species and biovars performed around the World (12,15-17), but in Iran, no study was done especially on clinical samples by this method, and it is the first time that a study is done on molecular typing of B. melitensis and B. abortus isolated from blood samples.

\section{Objectives}

The aims of this study were Molecular typing and Molecular Epidemiology of B. melitensis and B. abortus from human blood samples based on PCR assay to find prevalence biovars in human blood.

\section{Materials and Methods}

\subsection{Blood Samples Collection}

160 Clinical specimens were received from patients who referred to Kerman clinical centers with Brucellosis detection as they had measurable antibody titers 1/80 during the last two years. $5 \mathrm{ml}$ blood was taken from patients and the blood samples were transferred to laboratory and were kept in $-20^{\circ} \mathrm{C}$.

\subsection{DNA Extraction}

A modification of the method was described by QueipoOrtuño et al (18). Briefly, $0.5 \mathrm{ml}$ of blood samples with 1 $\mathrm{ml}$ of erythrocyte lyses' solution (320 mM saccharose, 5 mM MgCl2, 1\% Triton X-100, 10 mM Tris HCl [pH 7.5]) were mixed and centrifuged at $15000 \times \mathrm{g}$ for $2 \mathrm{~min}$. The supernatant was discarded, and the above steps were repeated for four times until the pellet lost all reddish coloring. Four hundred microliters of nucleic lyses' buffer(1\% SDS ,10 mM Tris-Hcl, 10mM EDTA, 10 mM Sodium Acetate [pH 8]) containing proteinase $\mathrm{K}(10 \mathrm{mg} / \mathrm{ml})$ were mixed and incubated for $30 \mathrm{~min}$ at $55^{\circ} \mathrm{C}$ in shaker incubator. Then, $100 \mathrm{ml}$ of ammonium acetate $(7.5 \mathrm{M})$ was added and centrifuged at $15,000 \times \mathrm{g}$ for $10 \mathrm{~min}$. To the supernatant, two volumes of absolute ethanol were added, and after centrifuging at $15,000 \times \mathrm{g}$ for $10 \mathrm{~min}$, the pellets were dissolved in $25 \mu \mathrm{l}$ of TE buffer ( $\mathrm{pH} 8.0$ ) and stored at $4^{\circ} \mathrm{C}$ for PCR or at $-20^{\circ} \mathrm{C}$ for long-term storage.

\subsection{Amplification of omp2a and omp2b Fragments}

Cloackaert et al. (13) designed primers for amplification of omp2a and omp2b fragments and their sequences are shown in Table 1. Each PCR reaction mixture contained; $1 \mathrm{X}$ PCR buffer, $2 \mathrm{mM} \mathrm{MgCl} 2,1 \mu$ l template DNA $(0.5 \mu \mathrm{g}), 0.15$ mMdNTP, 2.5 U Taq DNA polymerase, 20 pmol of each forward and reverse primers and sterile distilled water up to $50 \mu \mathrm{l}$. According to the following program, PCR for omp2a was performed in a GenAmp PCR system (Eppendorf, Germany): pre-denaturation for $5 \mathrm{~min}$ at $94^{\circ} \mathrm{C}$ followed by 35 cycles each containing denaturation at $94^{\circ} \mathrm{C}$ for $60 \mathrm{sec}$, annealing at $50^{\circ} \mathrm{C}$ for $120 \mathrm{sec}$ and extension at $72^{\circ} \mathrm{C}$ for $180 \mathrm{sec}$, followed by final extension at $72^{\circ} \mathrm{C}$ for $7 \mathrm{~min}$. Also PCR for omp2b was performed according to the following program: Pre-denaturation for $5 \mathrm{~min}$ at $94^{\circ} \mathrm{C}$ followed by 35 cycles each containing denaturation at $94^{\circ} \mathrm{C}$ for 45 sec, annealing at $58^{\circ} \mathrm{C}$ for $60 \mathrm{sec}$ and extension at $72^{\circ} \mathrm{C}$ for $60 \mathrm{sec}$, followed by final extension at $72^{\circ} \mathrm{C}$ for $7 \mathrm{~min}$. Then, The PCR products were analyzed using the electrophoresis technique on $2 \%$ agarose gel for 1 hour at $25 \mathrm{~mA}$, stained by SYBR-Green and visualized under UV transilluminator (Figure 1).

Table 1. Primers for Amplification of omp2a and omp2b Fragments

\begin{tabular}{ll}
\hline Primer & Sequence \\
\hline omp2a F & 5'-GGCTATTCAAAATTCTGGCG-3' \\
\hline omp2a R & 5'-ATCGATTCTCACGCTTTCGT-3' \\
\hline omp2b F & 5'-CCTTCAGCCAAATCAGAATG-3' \\
\hline omp2b R & 5'-GGTCAGCATAAAAAGCAAGC-3' \\
\hline
\end{tabular}

Figure 1. Agarose Gel Electrophoresis of PCR Amplified Products Gener ated From DNA Samples

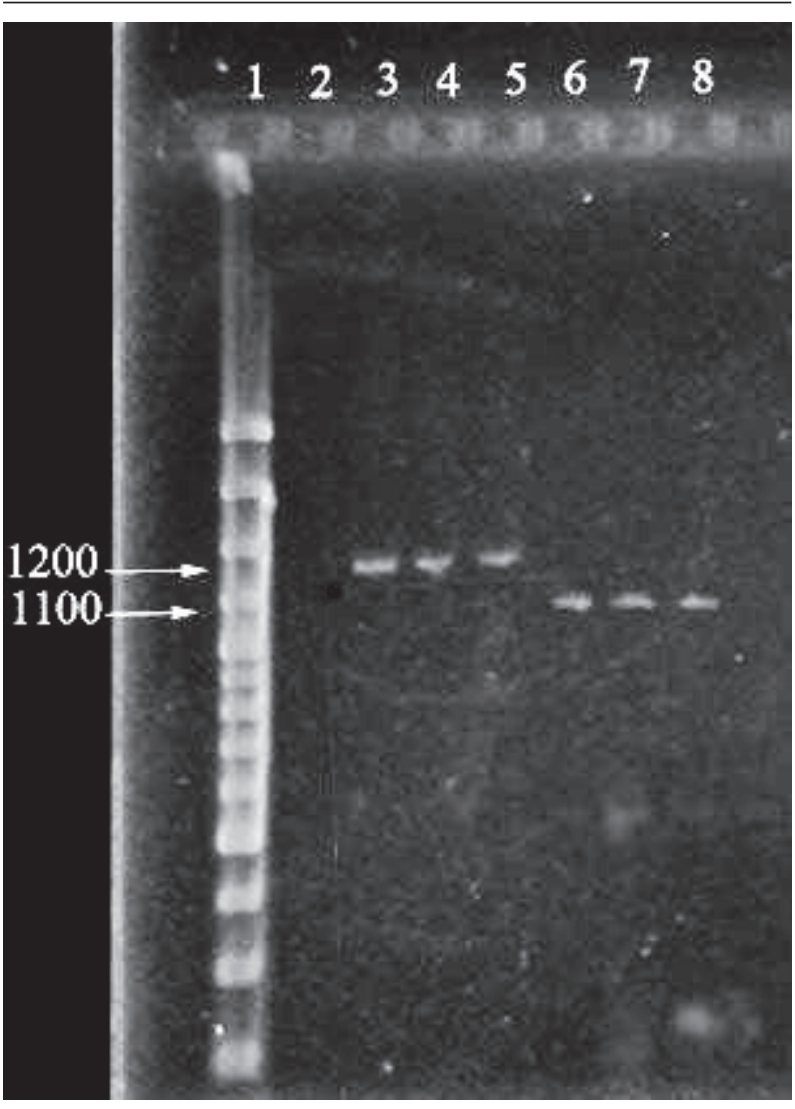

Lane 1 shows DNA size marker (10obp DNA ladder). Lane 2 is negative control. Lanes3 and 4 show amplified locus of omp2b. Lane 6 and 7 show amplified locus of omp2a, Lane 5 and 8 is positive control. 
Finally, amplification products were further evaluated restriction digestion procedures.

\subsection{Enzymatic Digestion}

To identify polymorphisms, the amplified products were subject to restriction enzymes. For enzymatic digestion or PCR-RFLP, the following $15 \mu \mathrm{l}$ reactions were prepared for positive samples. $6 \mu$ free nuclease sterile water, $1.7 \mu$ l enzyme buffers, $0.3 \mu$ l restriction enzyme (10$20 \mathrm{U})$, and $7 \mu \mathrm{l}$ of PCR product. After providing the above reaction, micro tubes were put in the water bath for $2 \mathrm{hrs}$ at $37^{\circ} \mathrm{C}$. After 2 hours, products of RFLP were electrophoresed on $2 \%$ gel agarose. Finally the size of the fragments which were resulted from enzymatic digestion of all positive PCR samples compared with each other and according to the results of Cloackaert et al.(15), the biovars were identified.

\subsection{Statistical Analysis}

Statistical analysis was conducted to determine how many samples were positive for each bacterium, as well as those positive for two bacterial species. Perspective analyses were performed and data rounded numerical values (percentage) were documented.

\section{Results}

In 160 blood samples studied by PCR technique, 52 cases obtained bands of 1100 bp foromp2alocus and $1200 \mathrm{bp}$ for omp2b locus which indicates that the samples are positive for Brucella (Figure 1).

According to Cloackaert et al. ( 13 ) regarding enzymatic digestion of the amplified fragments, and comparing the results of the present study with their obtained patterns, for 52 cases from digestion of omp2a fragment by Pst1 and Hinf1 enzymes, P3 and P2 Patterns were obtained respectively, and for omp2b, P1 and P1 patterns were resulted, which indicates the $B$. melitensis biovar 1 (Figure 2) ( 15 ),and for 33 cases (44.5\%) from digestion of omp2a fragment by Pst1 and Hinf1 enzymes, Patterns of P2 and P2 and for omp2b patterns of P1 and P1 were resulted respectively, which indicates the B. abortus one of the biovars 3, 5,6 or 9 (Figure 3). As a final conclusion, the used primers and enzymes in the current study showed that they were able to differentiate between $B$. melitensis biovars, but they cannot separate all of the B. abortus biovars from each other.

\section{Discussion}

Due to differences in the pathogenicity of Brucella species and biovars, with a view to epidemiology of brucellosis, recognition of Brucella biovars is important and hence typing of various strains is the main task of control centers of brucellosis and must be performed continuously $(9,13,15)$.
Figure 2. The Resulted Patterns of Enzymatic Digestion for B. melitensis Samples

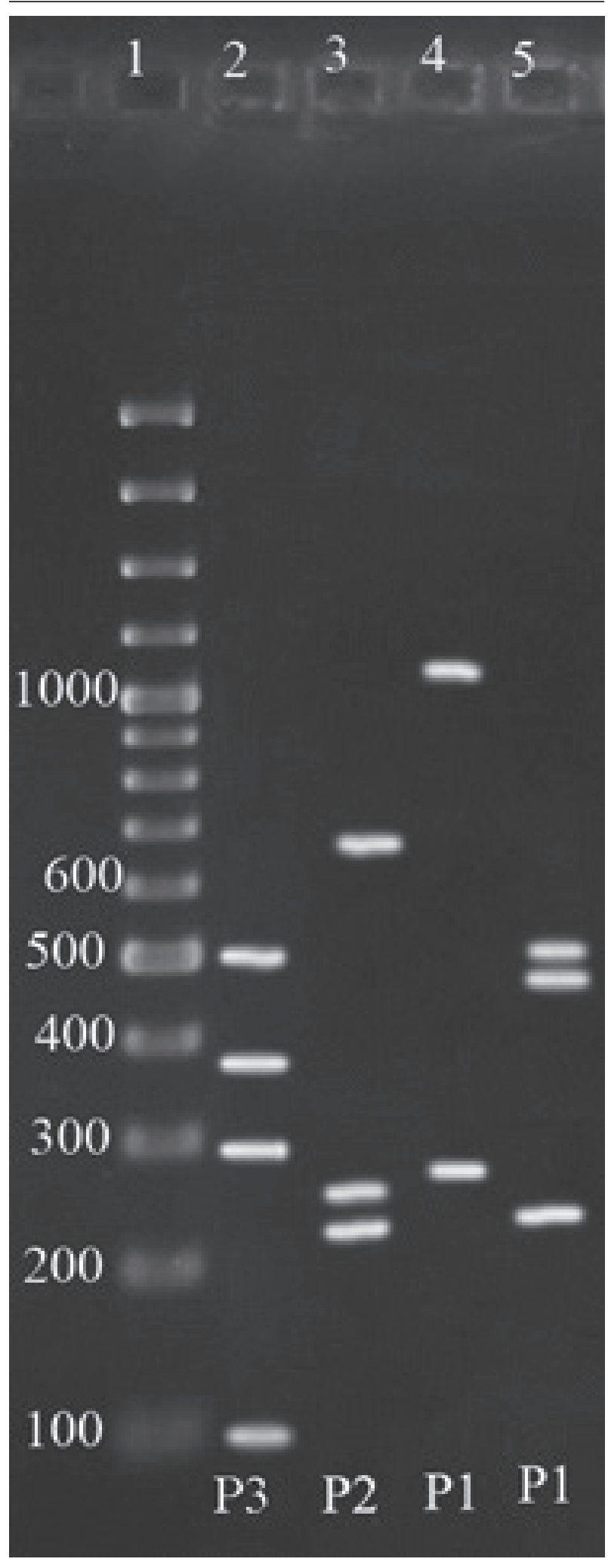

Lane 1 is DNA size marker (100bp DNA ladder), Lanes 2 and 3 are digestion of omp2a fragment by Pst1 and Hinf1 and Lanes 4 and 5 are digestion of omp2b fragment by Pst1 and Hinf1. 
Figure 3. The Resulted Patterns of Enzymatic Digestion for B. abortus Samples

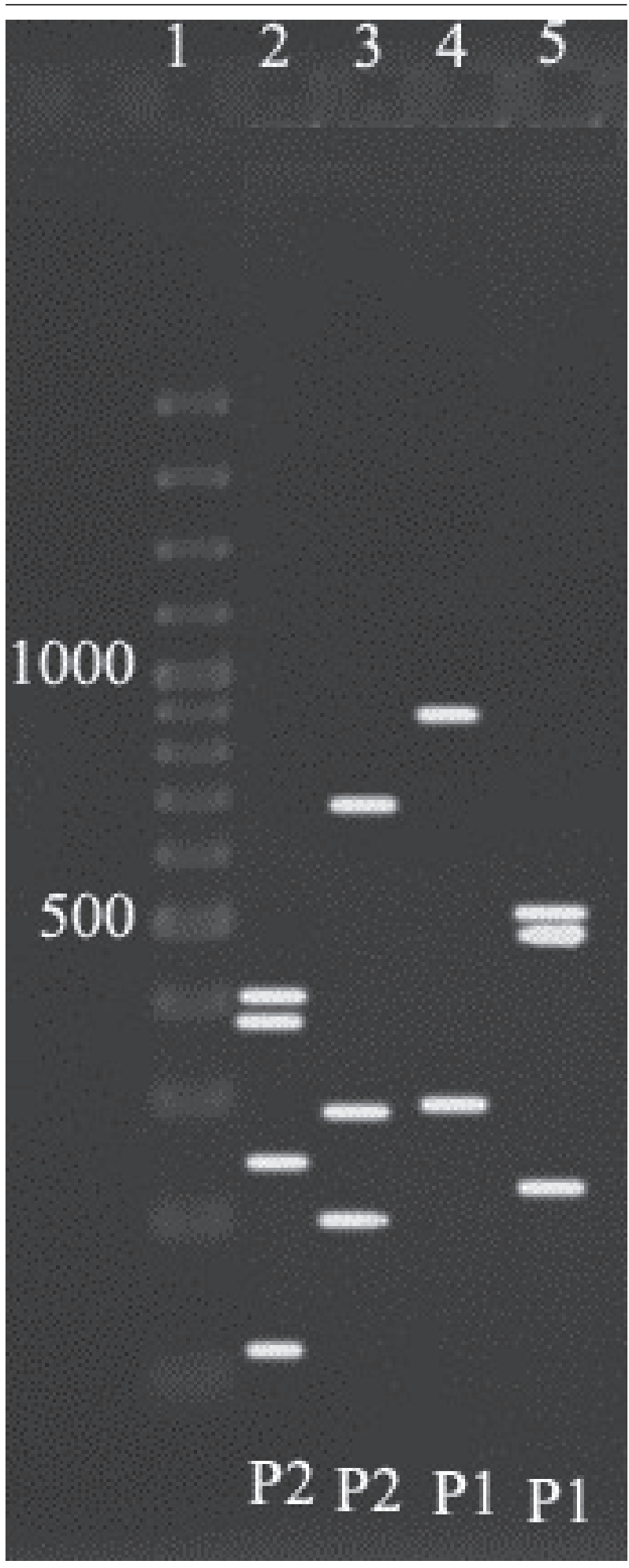

Lane 1 is DNA size marker (100 bp DNA ladder). Lanes 2 and 3 are digestion of omp2a fragment by Pst1 and Hinf1. Lanes 4 and 5 are digestion of omp2b fragment by Pst1 and Hinf1.
Distinction between the Brucella species and biovars in the past was mainly based on phenotypic characteristics. Today, with advancement of molecular techniques, several molecular typing methods to find DNA polymorphism are used, which are capable to identify Brucella biovars and species. The PBR assay is a technique used for typing $(9,10,19)$. The current study used this technique to determine the species and biovars of $B$. abortus and B. melitensis isolated from clinical specimens in Iran.

Different genetic fragments such as omp31, 16srDNA, omp2 and so on are used in different studies, to identify and differentiate Brucella species and biovars, which could not show ability to differentiate Brucella biovars completely $(14,20,21)$. Therefore, in subsequent studies especially in Cloackaert et al. study, omp2a and omp2b fragments and several restriction enzymes were used (15). These primers and enzymes were used in different parts of the world by different people, also in central parts of Iran they were used by Salehi et al. for molecular typing of common Brucella biovars (15-17, 22).

Results of all these studies, like those of the current study showed that the primers and enzymes are able to differentiate $B$. melitensis biovars but could not distinguish all of the B. abortus biovars from each other. However, present study differs from most of the studies in type of sample; in the current study human clinical samples were used whereas the others used animal samples. Also compared with the studies in Iran; there were differences, such as sample types, the enzymes used, and the sample figure. Salehi et al. by one or two pairs of primers and an enzyme identified Brucella isolated from animal samples (22). But in the current study, isolated Brucella from clinical samples were typed with two pairs of primers and two restriction enzymes. They were not able to differentiate between other B. melitensis biovars and biovars of B. abortus, but results of the current study showed that two species can be differentiated from each other and one can determine their biovars.

The results of this study like others in different parts of Iran showed that B. melitensis biovar 1 is the predominant form of these species in Iran $(23,24)$. Results of the current study showed that one of the B. abortus biovars 3, 5, 6 and 9 is the dominant form of these species, according to the previous studies in Iran, the biovar 3 was more likely $(23,24)$.

Same as the results of other studies in other parts of the world, the current study (15-17) showed that the PCR-RFLP techniques, by the primers and enzymes, were able to differentiate species and biovars of B. abortus and B. melitensis in clinical samples well. So they can be used to molecular typing of biovars isolated from different samples. Also comparing the obtained results with those of the other studies showed that the dominant pattern which causes the disease of brucellosis, especially B. melitensis, was not different in Iran, so, control and preventive measures of 
relevant organizations were appropriate and this trend should continue.

\section{Acknowledgements}

None declared.

\section{Authors' Contribution}

None declared.

\section{Financial Disclosure}

The authors declare no conflict of interest.

\section{Funding/Support}

This study was supported by the fund granted by the Molecular Biology Research Center, Baqiyatallah University of Medical Sciences, No. BMSU/MBRC- 90-8. Refer-

\section{ences}

1. Cutler SJ, Whatmore AM, Commander NJ. Brucellosis--new aspects of an old disease. J Appl Microbiol. 2005;98(6):1270-81.

2. Christopher S, Umapathy BL, Ravikumar KL. Brucellosis: review on the recent trends in pathogenicity and laboratory diagnosis. J Lab Physicians. 2010;2(2):55-60.

3. Guerra H. The brucellae and their success as pathogens. Crit Rev Microbiol. 2007;33(4):325-31.

4. Davar SS, Reza AM, Sahar K, Mehdi SS, Arfa M. Biological and immunological characteristics of Brucella abortus \$99 major outer membrane proteins. Jundishapur J Microbiol. 2012;4(1):29-36.

5. Shapouri R, Rahnema M. Evaluation of antimicrobial effect of hops extracts on intramacrophages Brucella abortus and B. melitensis. Jundishapur J Microbiol. 2011;4(2):S51-S58.

6. Seimenis A, Morelli D, Mantovani A. Zoonoses in the Mediterranean region. Ann Ist Super Sanita. 2006;42(4):437-45.

7. Pappas G, Memish ZA. Brucellosis in the middle East: a persistent medical, socioeconomic and political issue. I Chemother. 2007;19(3):243-8.

8. Li W, Raoult D, Fournier PE. Bacterial strain typing in the genomic era. FEMS Microbiol Rev. 2009;33(5):892-916.

9. Nagalingam M, Shome R, Balamurugan V, Shome BR, NarayanaRao K, et al. Molecular typing of Brucella species isolates from livestock and human. Trop Anim Health Prod. 2012;44(1):5-9.

10. Cerekci A, Kilic S, Bayraktar M, Uyanik MH, Yasar E, Esen B. [Comparison of conventional methods and real-time multiplex polymerase chain reaction for identification and typing of Brucella isolates of human origin]. Mikrobiyol Bul. 2011;45(3):392-400.
11. Wattiau P, Whatmore AM, Van Hessche M, Godfroid J, Fretin D. Nucleotide polymorphism-based single-tube test for robust molecular identification of all currently described Brucella species. Appl Environ Microbiol. 2011;77(18):6674-9.

12. Garcia-Yoldi D, Marin CM, Lopez-Goni I. Restriction site polymorphisms in the genes encoding new members of group 3 outer membrane protein family of Brucella spp. FEMS Microbiol Lett. 2005;245(1):79-84.

13. Lopez-Goni I, Garcia-Yoldi D, Marin CM, de Miguel MJ, Munoz PM, Blasco JM, et al. Evaluation of a multiplex PCR assay (Bruce-ladder) for molecular typing of all Brucella species, including the vaccine strains. J Clin Microbiol. 2008;46(10):3484-7.

14. Cloeckaert A, Vizcaino N, Paquet JY, Bowden RA, Elzer PH. Major outer membrane proteins of Brucella spp.: past, present and future. Vet Microbiol. 2002;90(1-4):229-47.

15. Cloeckaert A, Verger JM, Grayon M, Grepinet O. Restriction site polymorphism of the genes encoding the major $25 \mathrm{kDa}$ and 36 kDa outer-membrane proteins of Brucella. Microbiology. 1995;141 ( Pt 9):2111-21.

16. Al Dahouk S, Tomaso H, Prenger-Berninghoff E, Splettstoesser WD, Scholz HC, Neubauer H. Identification of brucella species and biotypes using polymerase chain reaction-restriction fragment length polymorphism (PCR-RFLP). Crit Rev Microbiol. 2005;31(4):191-6.

17. Ancora M, De Santis P, Di Giannatale E, Luciani M, Alessiani A. Molecular typing of Brucella field strains isolated in Italy. Vet Ital. 2005;41(1):51-5.

18. Queipo-Ortuno MI, Morata P, Ocon P, Manchado P, Colmenero JD. Rapid diagnosis of human brucellosis by peripheral-blood PCR assay. J Clin Microbiol. 1997;35(11):2927-30.

19. Mirnejad R, Doust RH, Kachuei R, Mortazavi SM, Khoobdel M, Ahamadi A. Simultaneous detection and differentiates of Brucella abortus and Brucella melitensis by combinatorial PCR. Asian Pac J Trop Med. 2012;5(1):24-8.

20. Vizcaino N, Kittelberger R, Cloeckaert A, Marin CM, Fernandez Lago L. Minor nucleotide substitutions in the omp31 gene of Brucella ovis result in antigenic differences in the major outer membrane protein that it encodes compared to those of the other Brucella species. Infect Immun. 2001;69(11):7020-8.

21. Da Costa M, Guillou JP, Garin-Bastuji B, Thiebaud M, Dubray G Specificity of six gene sequences for the detection of the genus Brucella by DNA amplification.J Appl Bacteriol. 1996;81(3):267-75.

22. Salehi M, Pishva E, Salehi R, Rahmani R. Isolation of Brucella abortus using PCR-RFLP analysis. Iran J Pub Health. 2006;35(4).

23. Najafi N, Ghassemian R, Davoody AR, Tayebi A. An unusual complication of a common endemic disease: clinical and laboratory aspects of patients with brucella epididymoorchitis in the north of Iran. BMC Res Notes. 2011;4:286.

24. Shareef JM. A review of serological investigations of brucellosis among farm animals and humans in northern provinces of iraq (1974-2004).J Vet Med B Infect Dis Vet Public Health. 2006;53 Suppl 1:38-40. 